\title{
Biological Removal of Azo and Triphenylmethane Dyes and Toxicity of Process By-Products
}

\author{
Wioletta Przystaś • Ewa Zabłocka-Godlewska • \\ Elżbieta Grabińska-Sota
}

Received: 30 May 2011 / Accepted: 21 September 2011 /Published online: 11 November 2011

(C) The Author(s) 2011. This article is published with open access at Springerlink.com

\begin{abstract}
Increasing environmental pollution is connected with broad applications of dyes and imperfection of dyeing technology. Decolourization of triphenylmethane brilliant green and disazo Evans blue by bacterial and fungal strains and toxicity (phyto- and zootoxicity) of degradation by-products were investigated. Influence of incubation method on dyes removal was evaluated (static, semi-static, shaken). Dead biomass was used for sorption estimation. Toxicity of treated dyes was measured to estimate possible influence on aquatic ecosystems. The zootoxicity test was done with Daphnia magna and phytotoxicity with Lemna minor. Samples were classified according to ACE 89/BE 2/D3 Final Report Commission EC. The best results of removal for all tested strains were reached in shaken samples. In opposite to fungi, bacterial strains decolourized brilliant green more effectively than Evans blue. The most effective bacterial strain was Erwinia spp. (s12) and fungal strains were Polyporus picipes (RWP17) and Pleurotus ostreatus (BWPH and MB). Decolourization of brilliant green was connected with decrease of zootoxicity (D. magna) and phytotoxicity (L. minor). Removal of Evans blue was connected with no
\end{abstract}

W. Przystaś $(\bowtie) \cdot$ E. Zabłocka-Godlewska •

E. Grabińska-Sota

Environmental Biotechnology Department,

Silesian University of Technology,

Akademicka 2a,

44-100 Gliwice, Poland

e-mail: wioletta.przystas@polsl.pl changes in zootoxicity and decrease of phytotoxicity in most of samples.

Keywords Decolourization - Azo dyes .

Triphenylmethane dyes $\cdot$ Phytotoxicity $\cdot$ Zootoxicity

\section{Introduction}

Losses of colourants during different stages of manufacture can reach even 10-15\%. Coloured wastewaters, containing such high concentrations of dyes, lead to surface water pollution. Dyes reduce light penetration and photosynthetic activity, cause deficiency of oxygen, are highly toxic and are mutagenic. Synthetic origin and complex aromatic structure make them more recalcitrant to biodegradation (Sani and Banerjee 1999; Azmi et al. 1998; Banat et al. 1996; Pointing and Vrijmoed 2000; Forgacs et al. 2004). Azo and triphenylmethane dyes are the largest classes of commercially produced colourants. Azo dyes are characterized by the presence of chromophoric azo group and triphenylmethane dyes by the presence of chromogen containing three phenyl groups bound by the central carbon atom. They are used for colouring paper, food, cosmetics, textiles, leather and in medical treatment and analysis (Swamy and Ramsay 1999; Somasiri et al. 2006; Padamavathy et al. 2003).

Colour reduction may be achieved by physicochemical as well as biological processes. The 
conventional physicochemical methods of dyes removal include flocculation, flotation, oxidation, reduction, ozonation, coagulation, membrane separation and adsorption. The most popular sorbent is activated carbon, but it is of relatively high price, generating operating costs and the problem with regeneration. All physicochemical technologies are mostly faster than biological but are more expensive. Deposits generated during decolourization processes do not solve the problem either (Azmi et al. 1998; Robinson et al. 2001; Somasiri et al. 2006).

Imperfection of colour removal with standard activated sludge is connected with changes in concentration and dyes composition, their toxicity as well as sludge adaptation to such unstable conditions (Azmi et al. 1998; Robinson et al. 2001). Therefore, there is still a growing need in finding an effective and low-cost method for the removal of dyes from wastewater. The most promising are the biological processes based on biosorption, bioaccumulation and biodegradation. These processes use low-cost biological materials as living or dead microorganisms. The simplest mechanism is biosorption onto the biomass; however, this process is similar to different physical adsorption mechanisms and is not suitable for longterm treatment. Biotransformation of dye structure can lead to formation of less toxic products or complete mineralization (Azmi et al. 1998; Pointing and Vrijmoed 2000; Robinson et al. 2001; Daiyong Deng et al. 2008). The aim of the present study was decolourization of disazo dye Evans blue and triphenylmethane dye brilliant green by living and dead bacterial and fungal biomass. There is lack of information about influence of cleaned wastewater on environment. This work consolidates effectiveness of dyes removal and toxicity of decolourization by-products.

\section{Materials and Methods}

\subsection{Organisms and Culture Conditions}

Fungal strains BWPH and MB (Pleurotus ostreatus), RWP17 (Polyporus picipes), DCA (Gloeophyllum odoratum) and G1 (Fusarium oxysporum GenBank accession number GU109337) were isolated with tissue method from fruit bodies taken from forest near Gliwice and strain G1 with dilution method from sawdust. Strains were grown in 300-ml flasks containing $150 \mathrm{ml}$ of YEPG medium (glucose $10 \mathrm{~g} / \mathrm{L}$, peptone $5 \mathrm{~g} / \mathrm{L}$, yeast extract $2 \mathrm{~g} / \mathrm{L}, \mathrm{MgSO}_{4} 0.5 \mathrm{~g} / \mathrm{L}$, $\mathrm{KH}_{2} \mathrm{PO}_{4} 1 \mathrm{~g} / \mathrm{L}, \mathrm{pH}$ 5.6). Two discs ( $\theta 5 \mathrm{~mm}$ ) of 7 days culture on MEA (Fluka Biochemica) were added to each flask. Bacterial strains s43 (Chryseomonas luteola), s45 (Burkholderia cepacia) and s12 (Erwinia spp.) were isolated from wastewater inlet at the wastewater treatment plant in Tychy (south Poland). Bacterial strains were identified by API $20 \mathrm{E}$ and 20NE (Biomerieux) and grown for $48 \mathrm{~h}$ on nutrient agar (Fluka Biochemika, Buchs, Switzerland). Slants with bacterial cultures were washed with physiological salt solution. Bacterial suspension density was estimated to be 5 in McFarland scale. Inoculum (1 mL) was added to $300-\mathrm{ml}$ flasks containing $100 \mathrm{~mL}$ of Kimura medium (glucose $20 \mathrm{~g} / \mathrm{L}$, peptone $5 \mathrm{~g} / \mathrm{L}$, yeast extract $2 \mathrm{~g} / \mathrm{L}$, $\mathrm{MgSO}_{4} 0.5 \mathrm{~g} / \mathrm{L}, \mathrm{KH}_{2} \mathrm{PO}_{4} 1 \mathrm{~g} / \mathrm{L}, \mathrm{pH}$ 6.8).

Water solutions of triphenylmethane dye brilliant green (POCh, Gliwice, Poland) and disazo dye Evans blue (Sigma-Aldrich, St. Louis, MO) were filter sterilized (milipore cellulose filters $\theta 0.20 \mu \mathrm{m}$ ) and added to 5-day-old fungal and 2-day-old bacterial samples. Concentrations of dyes were determined experimentally in tube test as maximal dye content with removal higher than $50 \%$ after 5 days. Final dyes concentrations in samples were $0.05 \mathrm{~g} / \mathrm{L}$ for both dyes in bacterial cultures; in fungal samples, brilliant green content was $0.06 \mathrm{~g} / \mathrm{L}$ and Evans blue $0.15 \mathrm{~g} / \mathrm{L}$. Control samples with dyes were prepared on sterile media used for microorganisms cultures (YEPG and Kimura medium, respectively, for fungal and bacterial strains) and were incubated in the same conditions as inoculated samples.

Cultures were incubated in static, semi-static and shaken conditions in $26^{\circ} \mathrm{C}$. Fungal strains were incubated only in static and shaken conditions. Dead biomass was used for estimation of biosorption and was obtained by samples autoclaving for $15 \mathrm{~min}$ $\left(121^{\circ} \mathrm{C}, 1.5 \mathrm{~atm}\right)$.

\subsection{Measurement of Decolourization Effectiveness and Samples Toxicity}

Absorbance was measured after 1, 6, 24, 48, 72, 96 and $120 \mathrm{~h}$ (UV-VIS spectrophotometer Hitachi U1900). The wavelength for brilliant green $(624 \mathrm{~nm})$ and for Evans blue $(606 \mathrm{~nm})$ were determined experimentally as the wave with maximal absorbance. Percentage dye 
removal was calculated according to the formula: $R$ $(\%)=((C-S) / C) \times 100 \%$; where $C$-current concentration of dye in a control sample (milligrams per litre), $S$-current residue concentration of dye in samples with bacteria or fungi biomass (milligrams per litre).

The zootoxicity was evaluated using Daphnia magna (OECD 202) and phytotoxicity using OECD Lemna sp. growth inhibition test number 221. Samples were classified according to ACE 89/BE 2/D3 Final Report Commission EC.

\section{Results and Discussion}

Wastewater cleaning technologies involve physicochemical as well as biological methods. Microorganisms such as bacteria, algae and fungi are involved in decomposition of many complex compounds also synthetic dyes. Majority of deolourization studies are based on bacterial and fungal processes. Bacterial dyes removal can be a consequence of biodegradation, biotransformation and biosorption
Fig. 1 Removal of dyes by bacterial strains in shaken samples (a brilliant green; b Evans blue)
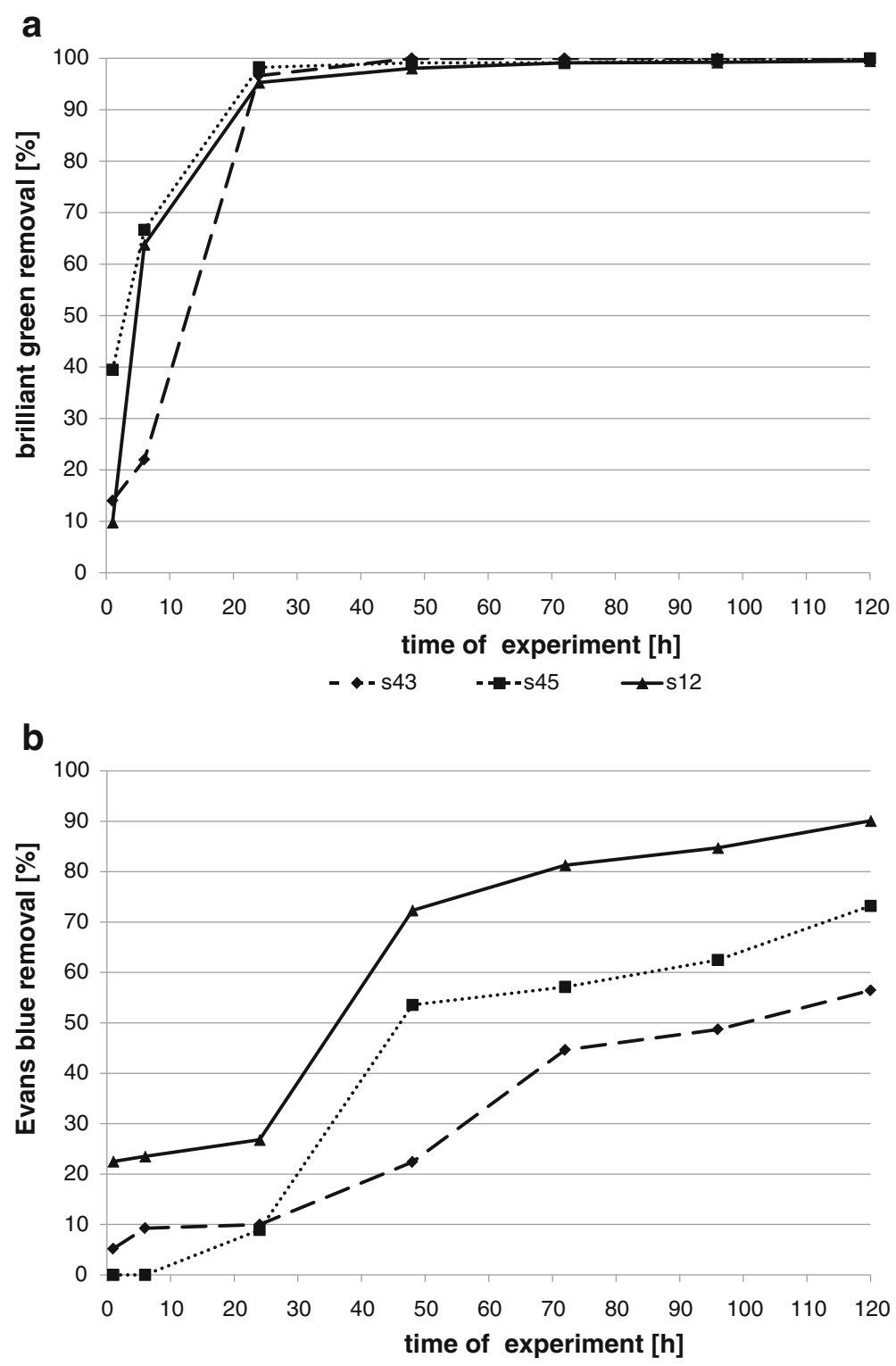

- s43 - - - s45 t-s12 
on living and/or dead biomass. Apart from mentioned above, fungal studies are concentrated also on usage of immobilized enzymes (Banat et al. 1996; Azmi et al. 1998; Sani and Banerjee 1999; Swamy and Ramsay 1999; Pointing and Vrijmoed 2000; Padamavathy et al. 2003; Forgacs et al. 2004; Daiyong Deng et al. 2008; Przystaś et al. 2009; Zabłocka-Godlewska et al. 2009).

Biomass growth conditions had a great influence on decolourization effectiveness (Figs. 1, 2, 3, 4 and 5). Sorption is mostly the first step of dye removal, and this process is different for each strain what depends on cell wall structure, dye properties and process conditions. Quantity of dyes in samples that differs from one strain to another especially during first hours of experiment (1-6 h) are probably the result of biosorption. All tested bacterial strains removed triphenylmethane brilliant green much better in shaken (Fig. 1) and semi-static conditions (Fig. 2). After $24 \mathrm{~h}$ in shaken samples, concentration of this dye was 95-98\% lower than in control (less than $0.0025 \mathrm{~g} / \mathrm{L}$ to comparison with control dye concentration $0.048 \mathrm{~g} / \mathrm{L}$ ). Similar results were reached in semi-static conditions after
Fig. 2 Removal of dyes by bacterial strains in semistatic samples (a brilliant green; b Evans blue)
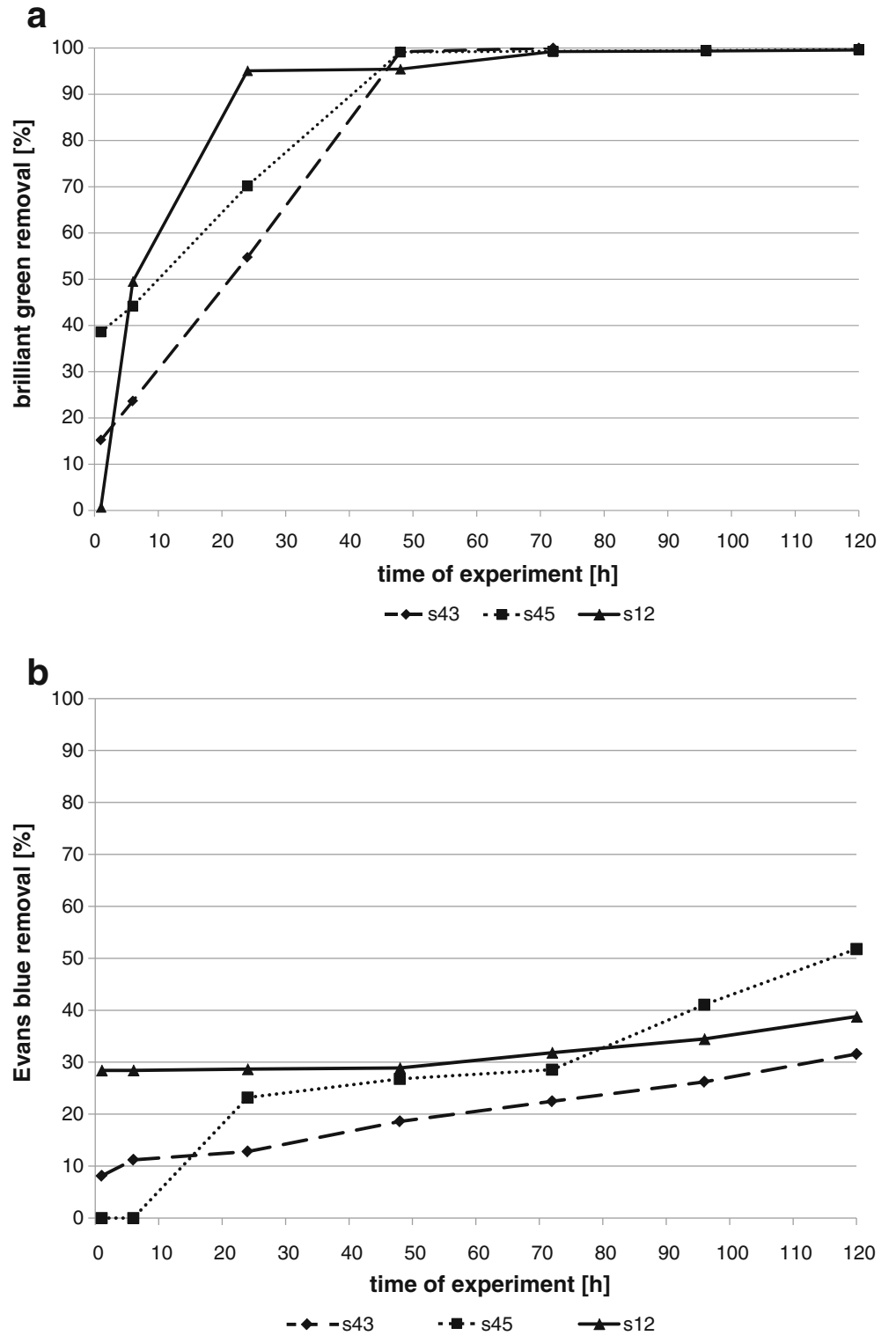
Fig. 3 Removal of dyes by bacterial strains in static samples (a brilliant green; b Evans blue)
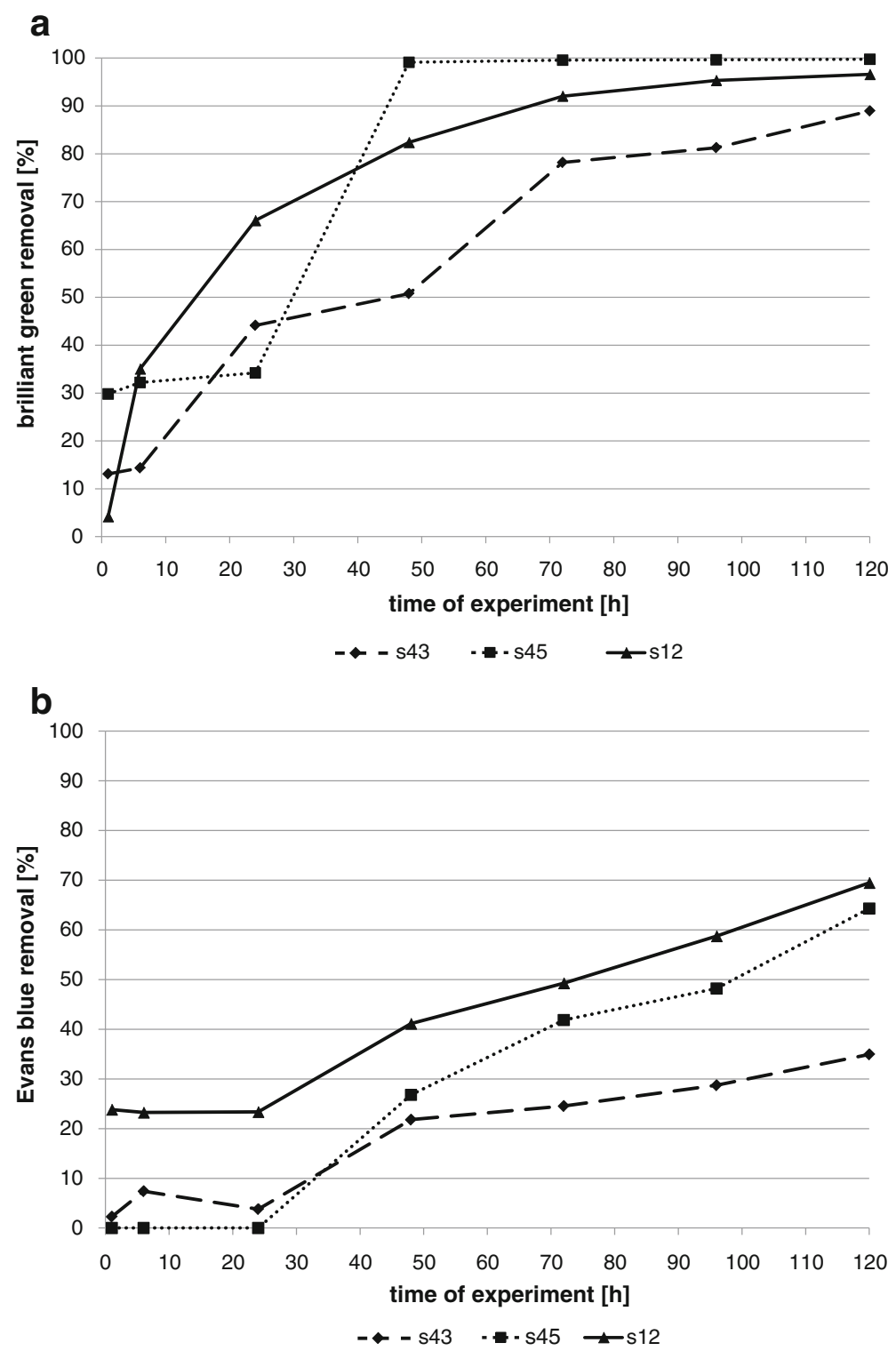

$48 \mathrm{~h}$ and in static after $96 \mathrm{~h}$ (Figs. 2 and 3). Results obtained for $\mathrm{s} 43$ in static samples are slightly worse than those for the other strains. Removal of brilliant green in static conditions after $96 \mathrm{~h}$ was $95-100 \%$ for strains $\mathrm{s} 45$ and $\mathrm{s} 12$ and $81 \%$ for strain $\mathrm{s} 43$. Sarnaik and Kanekar (1999) have reported the reduction of methyl violet by Pseudomonas mendocina in aerated samples in $99 \%$ after 24 h. Kurthia sp. tested by Kumar Sani and Chand Banerjee (1999) removed different tested triphenylmethane dyes even completely after $30 \mathrm{~min}$, and effectiveness depended on dye concentration. Deng et al. (2008) tested
Bacillus cereus strain DC11 on malachite green. After $3 \mathrm{~h}$ of incubation in static and microaerophilic conditions, decolourization was more than $96 \%$ in comparison with less than $10 \%$ after $8 \mathrm{~h}$ in aerobic sample.

The results indicate that better removal was also reached in shaken fungal samples (50-78\% after $24 \mathrm{~h}$ and $74-95 \%$ after $120 \mathrm{~h}$ ). In static conditions, decolourization reached $49-54 \%$ after $24 \mathrm{~h}$ and $57-$ $79 \%$ after $120 \mathrm{~h}$ (Figs. 4 and 5). Only strain G1 removed brilliant green better in static than in shaken samples $(81 \%$ and $78 \%$, respectively). BWPH strain 
Fig. 4 Removal of dyes by fungal strains in shaken samples (a brilliant green; b Evans blue)

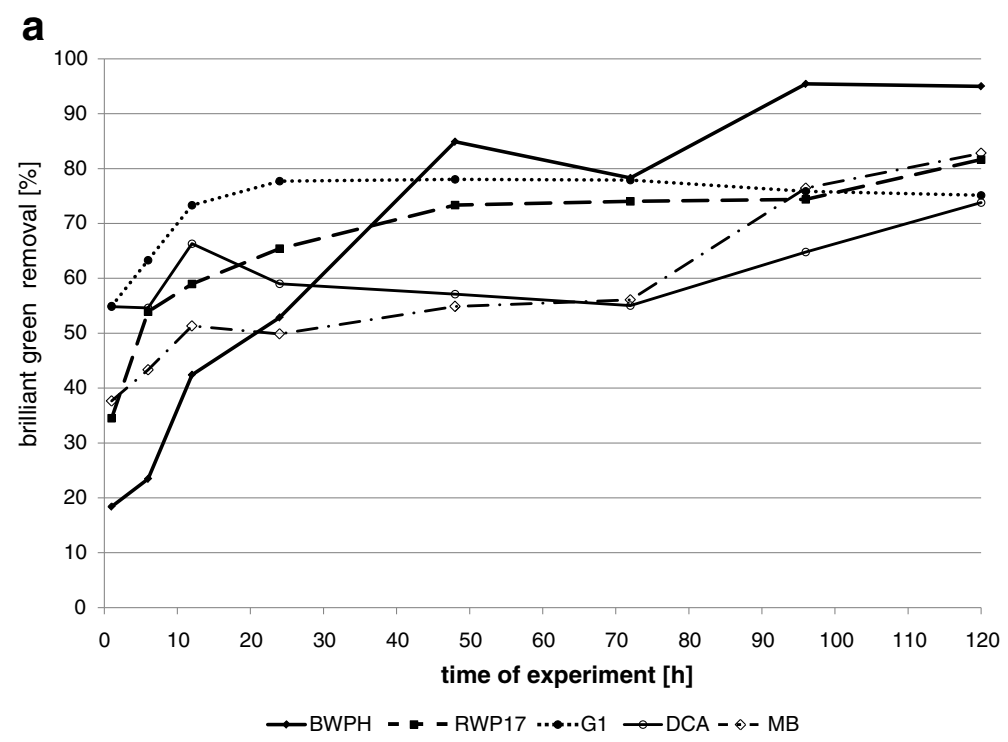

b

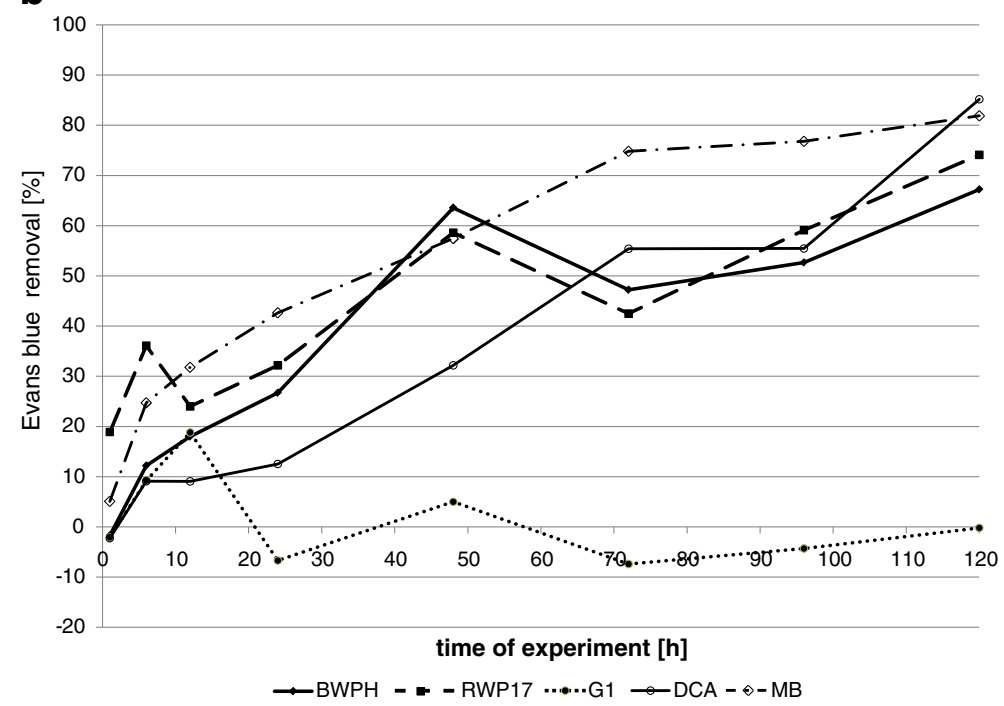

reduced concentration of brilliant green up to $95 \%$ in more aerated conditions and $71.6 \%$ in static samples. In a previous static test, this strain removed only 63.8\% after $168 \mathrm{~h}$ (Przystaś et al. 2009). As we can see, shaking improved medium aeration and contact of dye with white rot fungi biomass. Strain RWP17 removed up to $81.6 \%$ in shaken samples, $79.3 \%$ in static flasks and in previous static experiments $62.5 \%$ after 7 days (Zabłocka-Godlewska et al. 2009) and 96.1\% after 10 days (Przystaś et al. 2009). Differences between results in shaken and static samples were noticed in research of Kwang-Soo Shin (2004) and Revankar and Lele (2007). Revankar and Lele reached better results of decolourization in agitated samples (almost $80 \%$ removal after $8 \mathrm{~h}$ ) than in static samples (less than $50 \%$ at the same time). Kwang-Soo Shin after the 3-day test noticed better dye removal in static conditions (90\% to compare with $40 \%$ in shaken conditions). The influence of oxygen and agitation conditions affecting enzymes activity is well described by Wesenberg et al. (2003). The most interesting results ( $>80 \%$ removal of brilliant green) were reached by wood-rotting fungi. High potential of such fungi in decolourization was proven by Knapp et al. (1995) Brilliant green as well as crystal violet were completely removed by Basidiomycetes. 
Fig. 5 Removal of dyes by fungal strains in static samples (a brilliant green; b Evans blue)

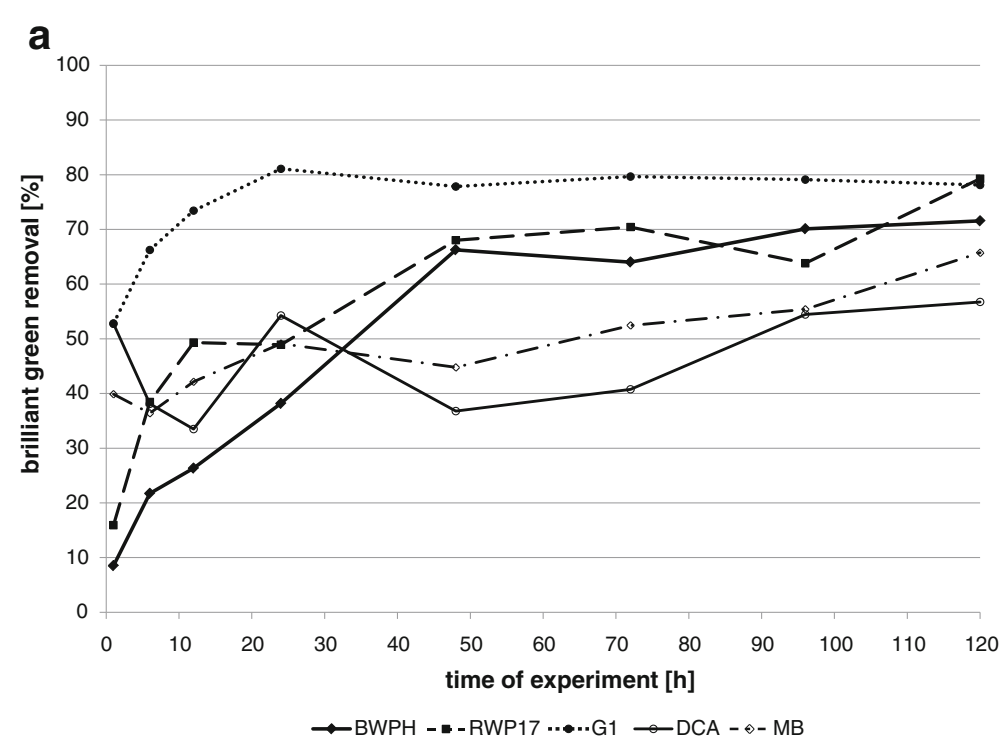

b

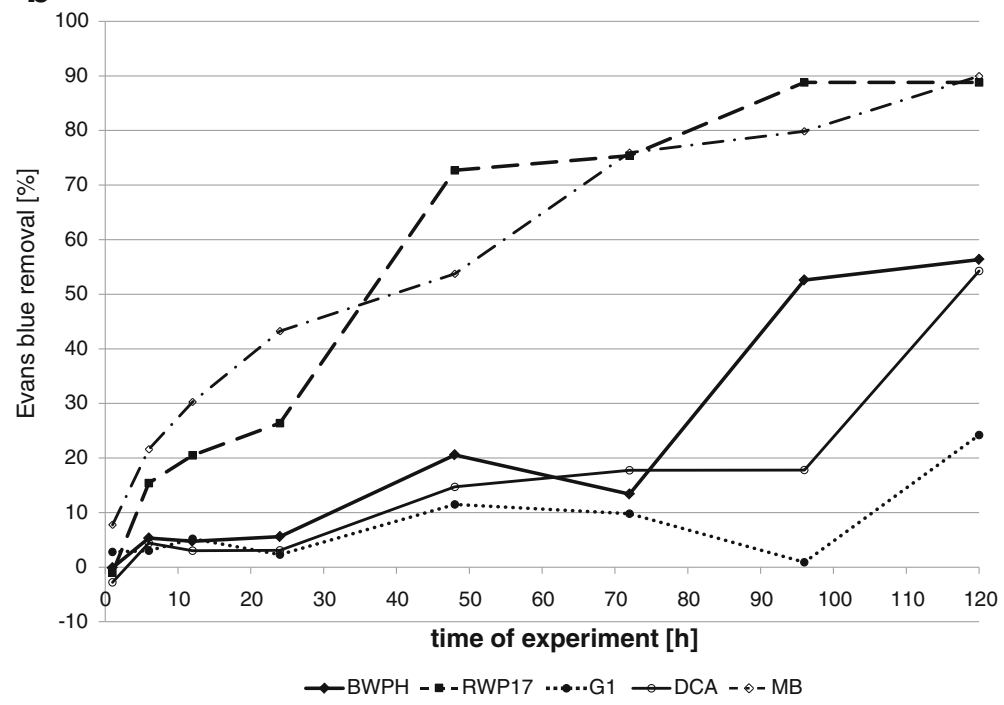

Very promising results were also reached by Novotny et al. (2004).

Evans blue removal by bacterial strains was slower than brilliant green decolourization (Figs. 1, 2 and 3). In shaken conditions, strain s12 removed $90 \%$ of colour after $120 \mathrm{~h}$. At the same time, in semi-static conditions and in static conditions, decolourization reached $39 \%$ and $69 \%$, respectively. Other strains (s43 and s45) removed 56-73\% in agitated samples, $32-52 \%$ in semi-static and $35-64 \%$ in static samples. Results were initially different. Strain $\mathrm{s} 45$ removed $23 \%$ of Evans blue in semi-static and $9 \%$ in shaken flasks (after $24 \mathrm{~h}$ ). No removal was noticed in static flasks. The same strain after $120 \mathrm{~h}$ reached removal $52 \%, 73 \%$ and $64 \%$, respectively. Azo dyes are generally resistant to attack by bacteria under aerobic conditions because bacterial azo reductase is inhibited by presence of oxygen. Competition in the oxidation of NADH and azo groups as electron receptors is confirmed (Moosvi et al. 2005). Isik and Sponza (2004) showed maximal decolourization (98\%) for Congo red in anaerobic conditions and the lowest in aerobic samples $(20 \%)$ in experiment with Escherichia coli. Static culture of bacterial consortium tested by Moosvi et al. (2005) exhibited lower growth rates but showed complete decolourization of reactive 
violet 5 after $37 \mathrm{~h}$ of incubation. In agitated samples, removal was lower than $20 \%$.

Decolourization of Evans blue by fungal strains also differed from one strain to another (Figs. 4 and 5). Secretion of pigments by fungal biomass was observed for strains MB, BWPH and G1 during growing on used media. Removal values lower than 0 in case of strain G1 was probably the effect of the secretion of dyes by the strain and the interaction of this colour with Evans blue.
Removal of Evans blue by strain MB (P. ostreatus) was faster than by other fungal strains (Figs. 4 and 5). After $24 \mathrm{~h}$ in static and shaken conditions, the removal reached about 43\%; after $120 \mathrm{~h}$ in static conditions, the dye concentration was $90 \%$ and in shaken $82 \%$ lower than in control. High effectiveness of dye removal was noticed also for strain RWP17, but changes of dye concentration in sample during experiment probably are the results of alternating sorption-desorption processes. Static conditions were

Table 1 Percentage removal of brilliant green and Evans blue and toxicity of samples after the end of experiment

\begin{tabular}{|c|c|c|c|c|c|c|c|}
\hline \multirow[t]{3}{*}{ Sample } & \multirow{3}{*}{$\begin{array}{l}\text { Incubation } \\
\text { method }\end{array}$} & \multirow{3}{*}{$\begin{array}{l}\text { Removal of brilliant } \\
\text { green [\%] } \\
120 \mathrm{~h}\end{array}$} & \multirow{3}{*}{$\begin{array}{l}\text { Removal of } \\
\text { Evans blue [\%] } \\
120 \mathrm{~h}\end{array}$} & \multicolumn{4}{|c|}{ Toxicity class (TUa) } \\
\hline & & & & \multicolumn{2}{|c|}{ Daphnia magna } & \multicolumn{2}{|l|}{ Lemna minor } \\
\hline & & & & $\begin{array}{l}\text { Brilliant } \\
\text { green }\end{array}$ & Evans blue & Brilliant green & Evans blue \\
\hline \multirow[t]{4}{*}{ S 12} & Static & $96.59 \pm 1.10$ & $38.78 \pm 0.62$ & III (5.63) & IV (62.5) & IV (64.10) & III (6.45) \\
\hline & Shaken & $99.49 \pm 0.80$ & $90.08 \pm 0.02$ & III (3.23) & III (9.1) & IV (31.95) & IV (20.00) \\
\hline & Semi-static & $99.58 \pm 0.28$ & $69.47 \pm 1.22$ & III (2.74) & IV (17.7) & IV (16.00) & III (9.10) \\
\hline & Dead biomass & $21.81 \pm 2.92$ & $23.84 \pm 2.11$ & IV (44.4) & IV (10.1) & IV (64.10) & IV (16.66) \\
\hline \multirow[t]{4}{*}{ S 43} & Static & $88.95 \pm 1.85$ & $31.57 \pm 1.12$ & III (4.55) & III (3.57) & III (7.69) & III (27.10) \\
\hline & Shaken & $100.00 \pm 0.88$ & $56.44 \pm 1.43$ & III (2.17) & III (5.71) & IV (45.66) & III (17.50) \\
\hline & Semi-static & $100.00 \pm 0.62$ & $34.94 \pm 0.76$ & III (1.72) & III (4.34) & IV (43.85) & III (14.5) \\
\hline & Dead biomass & $63.56 \pm 2.20$ & $34.96 \pm 1.02$ & IV (12.66) & III (1.61) & Non-toxic $(-)$ & III (32.90) \\
\hline \multirow[t]{4}{*}{ S 45} & Static & $99.74 \pm 0.98$ & $51.79 \pm 0.72$ & IV (14.22) & III (3.20) & IV (31.95) & IV (64.10) \\
\hline & Shaken & $100.00 \pm 0.08$ & $73.21 \pm 0.37$ & III (1.60) & III (4.57) & IV (25.64) & IV (10.57) \\
\hline & Semi-static & $99.67 \pm 0.12$ & $64.29 \pm 0.56$ & III (3.20) & III (3.20) & IV (42.74) & IV (42.74) \\
\hline & Dead biomass & $49.12 \pm 1.94$ & $78.00 \pm 2.38$ & IV (21.51) & III (4.20) & IV (17.45) & III (5.73) \\
\hline \multirow[t]{3}{*}{ BWPH } & Static & $71.55 \pm 3.25$ & $56.36 \pm 4.22$ & III (5.56) & III (9.10) & Non-toxic (-) & III (3.20) \\
\hline & Shaken & $95.00 \pm 0.27$ & $67.20 \pm 1.91$ & III (3.70) & III (5.90) & Non-toxic (-) & III (2.40) \\
\hline & Dead biomass & $48.85 \pm 8.25$ & $8.08 \pm 1.73$ & III (1.60) & III (1.50) & Non-toxic (-) & III (7.90) \\
\hline \multirow[t]{3}{*}{ RWP17 } & Static & $79.30 \pm 1.27$ & $88.80 \pm 0.12$ & III (4.39) & III (5.60) & Non-toxic (-) & IV (12.31) \\
\hline & Shaken & $81.64 \pm 0.94$ & $74.10 \pm 1.31$ & III (4.00) & III (4.01) & Non-toxic (-) & IV (19.22) \\
\hline & Dead biomass & $76.87 \pm 3.21$ & $71.4 \pm 2.07$ & III (4.36) & III (4.01) & Non-toxic (-) & IV (16.00) \\
\hline \multirow[t]{3}{*}{ G1 } & Static & $78.12 \pm 1.29$ & $24.20 \pm 1.76$ & III (5.34) & III (5.0) & Non-toxic (-) & III (4.20) \\
\hline & Shaken & $75.13 \pm 3.19$ & $-0.20 \pm 1.67$ & III (7.27) & III (4.53) & Non-toxic (-) & III (3.71) \\
\hline & Dead biomass & $75.03 \pm 1.21$ & $94.70 \pm 0.07$ & III (6.67) & III (2.00) & Non-toxic (-) & III (8.10) \\
\hline \multirow[t]{3}{*}{ DCA } & Static & $56.74 \pm 2.94$ & $54.26 \pm 2.33$ & IV (14.60) & III (5.30) & I (0.39) & III (9.60) \\
\hline & Shaken & $73.81 \pm 1.11$ & $85.18 \pm 0.25$ & IV (42.10) & IV (13.30) & III (3.12) & III (6.30) \\
\hline & Dead biomass & $47.89 \pm 2.21$ & $8.10 \pm 0.29$ & IV (51.90) & III (2.04) & III (7.37) & III $(9.80)$ \\
\hline \multirow[t]{5}{*}{ MB } & Static & $65.74 \pm 3.11$ & $89.97 \pm 0.11$ & IV (32.05) & IV (11.10) & III (1.83) & III (7.70) \\
\hline & Shaken & $82.80 \pm 0.25$ & $81.90 \pm 0.34$ & IV (29.41) & III (8.71) & II $(0.49)$ & III (8.10) \\
\hline & Dead biomass & $36.78 \pm 2.25$ & $30.98 \pm 1.27$ & IV (28.17) & III (3.40) & II $(0.41)$ & IV (11.70) \\
\hline & \multicolumn{3}{|c|}{ Control with dye } & $\mathrm{V}(153.85)$ & III (18.74/10.4) & IV (12.50) & IV (13.20) \\
\hline & \multicolumn{3}{|c|}{ Growth medium } & III (13.79) & III (13.79) & Non-toxic (-) & Non-toxic ( \\
\hline
\end{tabular}


more favourable for strain RWP17 and MB and shaken conditions for the other tested strains (except G1). In a previous study, the same strain (RWP17) removed tested dye added in lower concentration in $60.7 \%$ in static tubes (Przystaś et al. 2009). Strain DCA was more effective in shaken conditions (dye removal 85.2\%). Results, reached in previous (Przystaś et al. 2009) and actual experiment in static samples, were almost the same $(57.1 \%$ and $54.3 \%$ Evans blue removal, respectively). Decolourization effectiveness in our study is comparable with results of Novotny et al. (2004) where decolourization of Congo red reached $55.8 \%$ and other disazo dyes $99 \%$ in 2 weeks.
There are differences between the removal of both tested dyes. Brilliant green was faster and more effectively removed by bacterial than fungal strains. Disazo dye Evans blue was more bioavailable for fungal strains. Dye concentration three times higher than in bacterial samples was removed more effectively and in shorter time. Differences between organisms in decolourization of different dyes are well reported (Gill et al. 2001).

The majority of works is concentrated only on decolourization effectiveness and decolourization mechanism. There is lack of information about the influence of treated wastewater on environment. Removal of brilliant green was connected with the
Fig. 6 Sorption of dyes by dead biomass of bacterial strains (a brilliant green; b Evans blue)
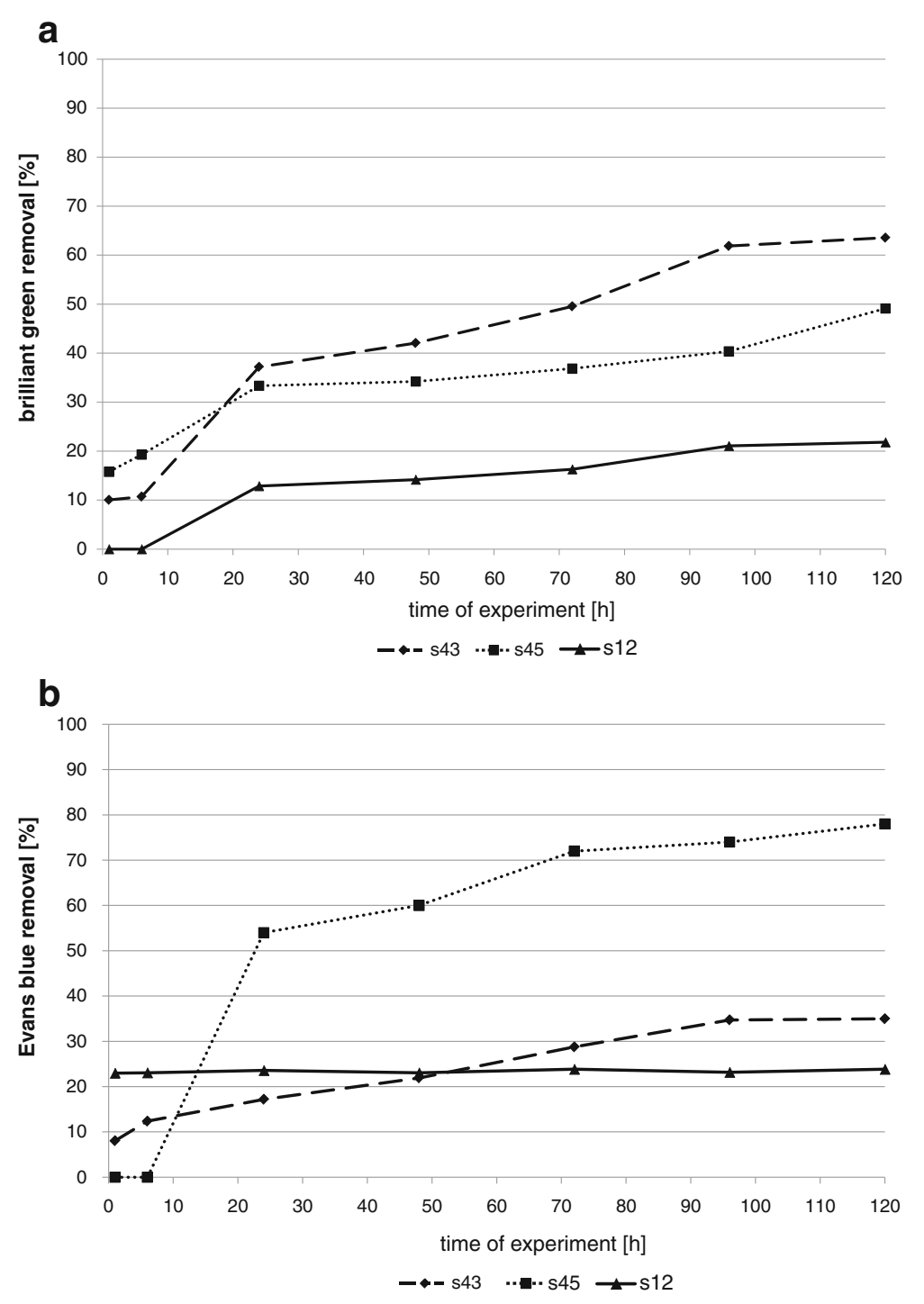
decrease of toxicity (Table 1). Control sample was classified as V class (extremely toxic) in the test with D. magna and IV class in the test with Lemna minor. Samples with bacterial and fungal strains after decolourization process were classified in majority to III class in the test with D. magna. In most cases, correlation between high removal and toxicity decrease was observed. In a previous study (ZabłockaGodlewska et al. 2009), bacterial and fungal samples with brilliant green were classified to IV class of toxicity in the test with D. magna and to III class of toxicity in the test with L. minor.
Control with Evans blue was classified in the test with $L$. minor to IV class and in the test with $D$. magna to III class. In the test with L. minor, samples with bacterial metabolites were classified similar to the control to IV class except in static sample with strain s43. Samples with fungal living biomass were classified mostly as non-toxic, except for strains DCA and MB classified to I-III classes. There was no decrease of toxicity in samples with bacterial and fungal strains in the test with D. magna. In static and semi-static samples with s12 strain and fungal strains DCA (shaken) and MB (static) increase of toxicity to
Fig. 7 Sorption of dyes by dead biomass of fungal strains (a brilliant green; b Evans blue)
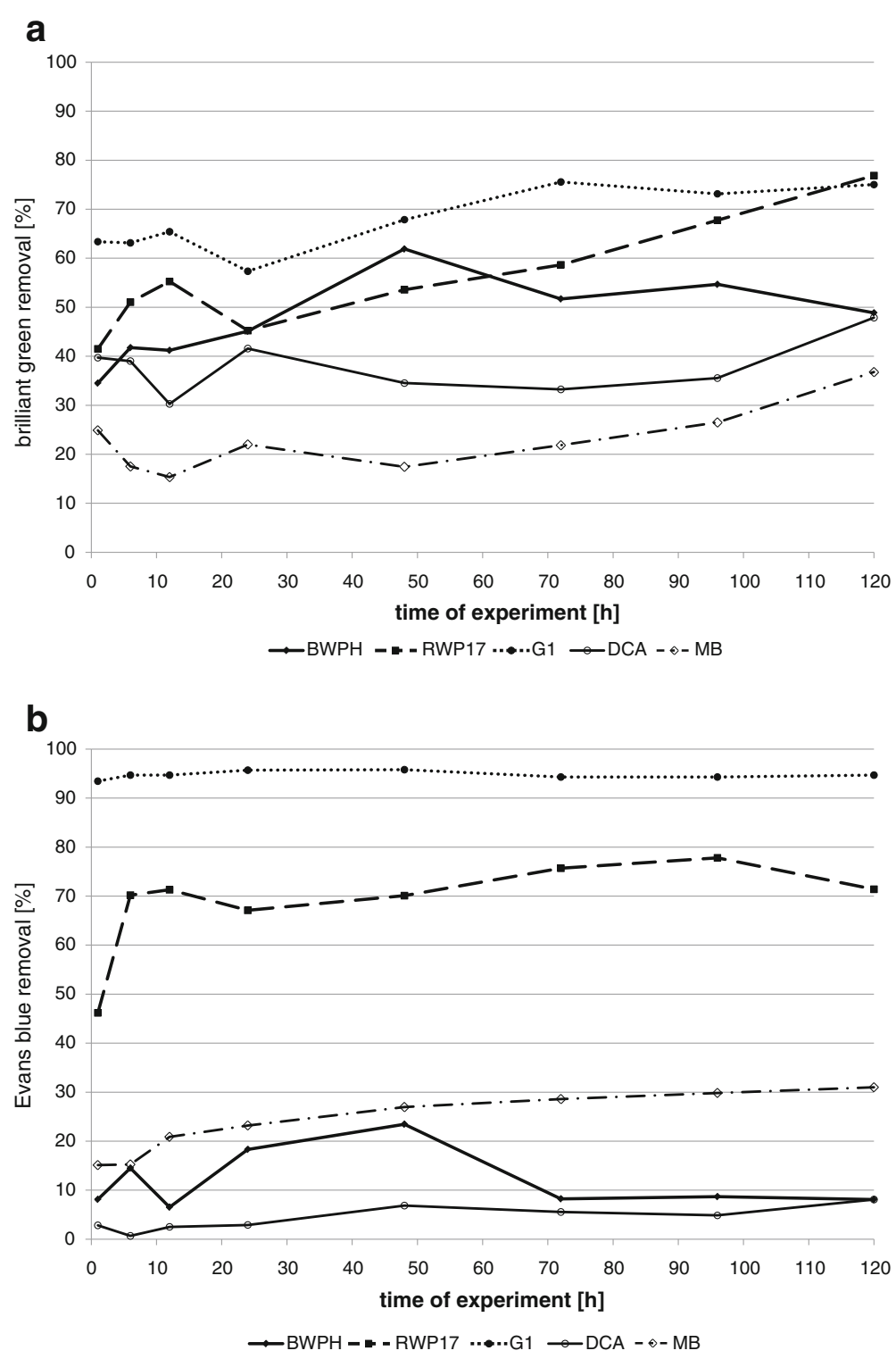
IV class were noticed. Removal effectiveness was not connected with changes of toxicity. The same situation was observed in the test with $L$. minor. Most of the samples with bacterial and fungal strains were classified to III class of toxicity but a few to IV class and control with dye.

Dead biomass of bacterial strains removed less dyes than living biomass. Both rate and effectiveness of sorption depended on strain and tested dye (Figs. 6 and 7). The lowest decolourization level was reached for strain s12 both for brilliant green and Evans blue (21.8\% and $23.8 \%$ after $120 \mathrm{~h}$, respectively). Absorption of Evans blue was higher for strain s45 (78\%) and that of the brilliant green by strain s43 (64\%).

Majority of fungal strains absorbed brilliant green on dead biomass in about $42-57 \%$ after $24 \mathrm{~h}$ and less than $77 \%$ after $120 \mathrm{~h}$. Strain MB absorbed only $37 \%$ after $120 \mathrm{~h}$. Evans blue was absorbed in 2.9-23.3\% after $24 \mathrm{~h}$ and $8.1-31 \%$ after $120 \mathrm{~h}$. Two strains (RWP17 and G1) absorbed Evans blue in higher extent. Strain G1 removed $95.7 \%$ of Evans blue in $24 \mathrm{~h}$, and no desorption was observed during $120 \mathrm{~h}$.

For the samples with living biomass, toxicity level was not correlated with effectiveness of dye sorption (Table 1). Most of fungal samples after the test with D. magna were classified as III class of toxicity (except DCA and MB for brilliant green). Toxicity class was not changed for s43 and s45 and increased for strain $\mathrm{s} 12$ for Evans blue. Decolourization of brilliant green by bacterial dead biomass resulted in toxicity decrease from $\mathrm{V}$ to IV class. In the test with L. minor samples with strains s12 and s45 and brilliant green were classified as IV class of toxicity, the same as control. The sample with strain s45 was classified as non-toxic. No toxic effect was observed for fungal decolourization, or samples were classified as II (MB) or III (DCA) class. No decrease of toxicity (s12, RWP17, MB) or low decrease to III class (s43, s45, BWPH, G1, DCA) was noticed for Evans blue.

\section{Conclusions}

Process conditions had a great influence on decolurization effectiveness. The best results of dye removal were reached mostly in more aerated shaken samples. In opposite to fungi bacterial strains were decolourizing brilliant green more effectively than Evans blue. Removal of brilliant green by both groups of organisms was mostly connected with decrease of zootoxicity (from V to III class) and phytotoxicity. Decolourization of Evans blue was not connected with changes of toxicity (mostly III class of toxicity).

Living biomass of tested strains removed brilliant green more effectively than dead biomass except for strain G1. High usefulness of tested microorganisms in decolourization processes (by biosorption and/or biotransformation) and decrease of toxicicity were proven for both dyes.

Acknowledgement This research has been supported by the Ministry of Science and Higher Education grant (2007-2010) research project number N523 178533 .

Open Access This article is distributed under the terms of the Creative Commons Attribution Noncommercial License which permits any noncommercial use, distribution, and reproduction in any medium, provided the original author(s) and source are credited.

\section{References}

Azmi, W., Sani, R. K., \& Banerjee, U. C. (1998). Biodegradation of triphenylmethane dyes. Enzyme and Microbial Technology, 22, 185-191.

Banat, I. M., Nigam, P., Singh, D., \& Marchant, R. (1996). Microbial decolorization of textile-dye-containing effluents: A review. Bioresource Technology, 58, 217-227.

Deng, D., Guo, J., Zeng, G., \& Sun, G. (2008). Decolorization of anthraquinone, triphenylmethane and azo dyes by a new isolated Bacillus cereus strain DC11q. International Biodeterioration and Biodegradation, 62, 263-269.

Forgacs, E., Cserhati, T., \& Oros, G. (2004). Removal of synthetic dyes from wastewaters: A review. Environmental International, 30, 953-971.

Gill, P. K., Arora, D. S., \& Chander, M. (2001). Biodecolourization of azo and triphenylmethane dyes by Dichomitus squalens and Phelbia spp. Journal of Industrial Microbiology and Biotechnology, 28, 201-203.

Isik, M., \& Sponza, D. T. (2004). Effect of oxygen on decolorization of azo dyes by Escherichia coli and Pseudomonas sp. and fate of aromatic amines. Process Biochemistry, 38, 1183-1192.

Knapp, J. S., Newby, P. S., \& Reece, L. P. (1995). Decolorization of wood-rotting basidiomycete fungi. Enzyme and Microbial Technology, 17, 664-668.

Moosvi, S., Keharia, H., \& Madamwar, D. (2005). Decolourization of textile dye Reactive Violet 5 by a newly isolated bacterial consortium RVM 11.1. World Journal of Microbiology and Biotechnology, 21, 667-672.

Novotny, C., Svobodova, K., Kasinath, A., \& Erbanova, P. (2004). Biodegradatioin of synthetic dyes by Irpex lacteus under various growth conditions. International Biodeterioration and Biodegradation, 54, 215-223. 
Padamavathy, S., Sandhya, S., Swaminathan, K., Subrahmanyam, Y. V., \& Kaul, S. N. (2003). Comparison of decolorization of reactive azo dyes by microorganisms isolated from various source. Journal of Environmental Sciences, 15, 628-632.

Pointing, S. B., \& Vrijmoed, L. L. P. (2000). Decolorization of azo and triphenylmethane dyes by Pycnoporus sanguineus producing laccase as the sole phenoloxidase. World Journal of Microbiology and Biotechnology, 16, 317-318.

Przystaś, W., Zabłocka-Godlewska, E., \& Grabińska-Sota, E. (2009). The screening of dyes decolorizing microorganisms strains. Polish Journal of Environmental Studies, 18 (2B), 69-73.

Revankar, M. S., \& Lele, S. S. (2007). Synthetic dye decolorization by white rot fungus, Ganoderma sp. WR-1. Bioresource Technology, 98, 775-780.

Robinson, T., McMullan, G., Marchant, R., \& Nigam, P. (2001). Remediation of dyes in textile effluent: A critical review on current treatment technologies with a proposed alternative. Bioresource Technology, 77, 247-255.

Sani, R. K., \& Banerjee, U. C. (1999). Decolorization of triphenylmethane dyes and textile and dye-stuff effluent by Kurthia sp. Enzyme and Microbial Technology, 24, 433-437.
Sarnaik, S., \& Kanekar, P. (1999). Biodegradation of methyl violet by Pseudomonas mendocina MCM B-402. Applied Microbiology and Biotechnology, 52, 251-254.

Shin, K.-S. (2004). The role of enzymes produced by white-rot fungus Irpex lacteus in the decolorization of the textile industry effluent. Journal of Microbiology, 41(1), 37-41.

Somasiri, W., Ruan, W., Xiufen, L., \& Jian, C. (2006). Decolourization of textile wastewater containing acid dyes in UASB reactor system under mixed anaerobic granular sludge. Electronic Journal of Environmental and Agricultural Food Chemistry, 5(1), 1224-1234.

Swamy, J., \& Ramsay, J. A. (1999). The evaluation of white-rot fungi in the decoloration of textile dyes. Enzyme and Microbial Technology, 24, 130-137.

Wesenberg, D., Kyriakides, I., \& Agathos, S. N. (2003). White-rot fungi and their enzymes for the treatment of industrial dye effluents. Biotechnology Advances, 22, $161-187$.

Zabłocka-Godlewska, E., Przystaś, W., \& Grabińska-Sota, E. (2009). Decolourization of triphenylmethane dyes and ecotoxicity of their end products. Environment Protection Engineering, 35(1), 161-169. 